
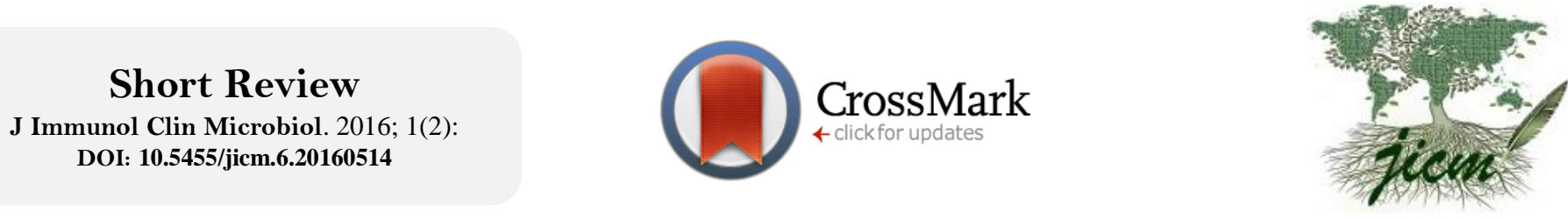

J Immunol Clin Microbiol

\title{
Immunology of Osteoporosis: A Short-Review
}

\author{
Volkan Subası ${ }^{1 *}$ \\ ${ }^{1}$ Private Dermancan Medical Center, Cukurova, Adana, Turkey.
}

\begin{abstract}
The osteoporosis pathogenesis is multifactorial and the immune system has an important role. Free radicals and the proteins or lipids that become glycated after exposure to sugars that may be related with bone resorption and inflammation.

It is now recognized that the receptor activator of NF- $\kappa B$ ligand (RANKL) has a major role at the bone resorbing. The physiological receptor of the biological activity of RANKL is managed by osteoprotegerin (OPG). The balance of RANKL and OPG in physiological bone turnover may control the bone density and pathological conditions. This review aims to provide a short overview of osteoimmunology in osteoporosis.
\end{abstract}

Key words: Osteoporosis, osteoimmunology, bone

\section{Introduction}

Osteoporosis is characterized by a decrease in bone density and which can lead to a risk of new fracture. Osteoporosis is a progressive disease and a global public health problem especially for women and older people of both sexes (1). Bone markers, bone microstructure and matrix, bone geometry, ingredients such as mineral density can be affected. The term of 'osteoimmunology' was coined in recent years. And afterward, this area has become a promising and intriguing field of research (24). This review aims to provide a short overview of osteoimmunology in osteoporosis.

\section{Osteoprotegerin and RANK-RANKL}

RANK-RANKL signaling system regulates the activation and function of multicore osteoclasts and by the way regulates bone resorption. Osteoprotegerin (OPG) encoded by the TNFRSF11B gene in humans and known as osteoclast genesis inhibitory factor (OCIF).
OPG is a member of the tumor necrosis factor (TNF) receptor family and a cytokine receptor. By binding to RANKL and prevent it from binding receptor RANK, OPG protects the bones from excessive resorption.

Therefore, the relationship between RANKL and OPG is the major marker of the bone density and bone integrity. Genetic experiments on these molecules have been emphasizing how important it is to fulfil the function of osteoclasts and osteoclast development $(5,6)$.

RANK has been discovered as an important ingredient in epithelial growth and cell differentiation. RANK is necessary for the formation of mammary glands, thymic epithelial cells and intestinal cells. Also, it has been shown to play a role in the pathogenesis of some forms of cancer (7-9). The increase in RANK expression in some types of cancer such as breast and colon cancer brought the allegations to be associated with RANKL.
*Corresponding Author: Volkan Subas1; Private Dermancan Medical Center, Turgut Ozal Bulv. No: 176 Çukurova, Adana, Turkey E-mail: vsubasi@yahoo.com Received: Apr 16, 2016 Accepted: Apr 27, 2016 Published Online: May 18, 2016.
This is an Open Access article distributed under the terms of the Creative Commons Attribution Non-Commercial License (http://creativecommons.org/licenses/bync/4.0/) which permits unrestricted non-commercial use, distribution, and reproduction in any medium, provided the original work is properly cited. 
RANK - RANKL pathway targeting drugs may revolutionize the treatment of arthritis, bone loss, oral squamous cell carcinoma and some cancer metastasis $(10,11)$.

OPG is released from many tissues including heart, lung, kidney, liver, brain, spinal cord, thyroid gland, stomach, intestines, bone and smooth muscle. And there are many functions that represent multiple possible functions. OPG's most important role is to protect the bone tissue (12).

\section{Bone Remodeling}

Bone remodeling is a process operating under the control of a variety of systemic and local factors of production function of osteoblasts and destruction function of osteoclasts

Parathyroid hormone $(\mathrm{PTH})$ is a major regulator of homeostasis of calcium ions (13). This hormone is mainly increases blood calcium concentration by acting on parathyroid hormone 1 receptors. PTH is secreted into the circulation in response to low blood calcium levels and show various effects on intestine, kidney and bone.

PTH regulates the activation, survival and differentiation of osteoclast and also release of interleukin-6 and RANKL by osteoblasts, in bone $(12,14)$.

\section{Role of $B$ and $T$ lymphocytes in bone}

In vitro and in vivo studies shows that, $\mathrm{T}$ lymphocytes activated by estrogen deficiency in postmenopausal osteoporosis can causes an increase in production of tumor necrosis factor alpha (TNF-A). In the absence of estrogen, TNF- producing $\mathrm{T}$ cells have a very important role in bone loss by the cytokines including, interleukin 7 , transforming growth factor- B and Interferon - G (15, 16). TNF directly and substantially increasing the sensitivity of the mature osteoclast to RANKL and macrophage colony stimulating factor by the way increase osteoclast formation and bone resorption. While TNF stimulates osteoclastic activity inhibits other hand osteoblastogenesis $(17,18)$.

In one study, bone loss would lead to the increased secretion of RANKL in B and $T$ cells have been suggested (19). B lymphocytes are known to play a role in regulation of osteoclast formation and bone resorption and also play a role RANK / RANKL / OPG system active regulation (20). In another study, percentage of CD5 + B cells with have been demonstrated to be correlated CTX- 1 serum level which is an indicator of the bone resorption in rheumatoid arthritis patients (21). In a study found that; CD19 + B lymphocytes and memory B cells were significantly lower number of various subpopulations in women with osteoporosis than in healthy controls (22).

\section{The Wnt signaling pathway and Biology of sclerostin}

Wnt signaling system is very important in the embodiment of bone development and bone mass. Wnt signaling loss due to mutations can lead to loss of bone mass. Sclerostin inhibits bone formation by blocking Wnt pathway (23-25).

\section{Therapeutic Aspects}

Recently RANKL / RANK / OPG system is more focused on targeted therapies. Denosumab is a monoclonal antibody molecule that targets RANKL recently developed by the pharmaceutical industry. This drug is a monoclonal $\operatorname{IgG}$ antibody which is genetically engineered in hamster ovary cells. It has high affinity to bind RANKL, the principle regulator of resorption (26). This drug inhibits osteoclast activity and production and in clinical trials showed that denosumab reduces bone resorption and improves bone mineral density (27). Denosumab significantly decreased the risk of osteoporotic vertebral and nonvertebral fractures in postmenopausal women (28).

Early and preclinical researches showed that sclerostin inhibitors can assist the bone formation and may be a new method of treatment for osteoporotic bone. One of the Sclerostin inhibitor molecules is romosozumab. A study showed that subcutaneous or intravenous injection of romosozumab can decrease bone turnover markers. Compared with placebo, treatment of romosozumab been shown to have positive effects on both cortical and trabecular bone mass $(29,30)$.

Another sclerostin inhibitor molecule is blosozumab. In a study single or multiple doses blosozumab given up to 8 weeks in postmenopausal women subcutaneously or intravenously and showed increase dose dependent lumbar densitometry scores but total hip scores did not change significantly (31). In an Another study about blosozumab treatment showed that; in total hip and 
femoral neck densitometry score could increase up to $6.3 \%(32)$.

\section{Conclusion}

Immune system by causing an imbalance between osteoclasts and osteoblasts can lead to osteoporosis. I believe that new treatment strategies will become more important which realizes the importance of the immune system in the osteoporosis treatment.

\section{Ethics Committee Approval: N/A.}

Informed Consent: N/A.

Peer-review: Externally peer-reviewed

Conflict of Interest: No conflict of interest was declared by the author.

Financial Disclosure: The author declared that this study has received no financial support.

\section{References}

1. Yeter A, Kavuncu V, Evcik FD, Demirdal ÜS, Subaşı V, Çakır T. Evalution the effects of raloxifene and risedronate on serum biochemical markers. Türk Osteoporoz derg 2014; 20 : 110-116.

2. Pietschmann P, Mechtcheriakova D, Meshcheryakova A, Föger-Samwald U, Ellinger I. Immunology of Osteoporosis: A Mini-Review. Gerontology 2016; 62: 128-137.

3. Arron JR, Choi Y. Bone versus immune system. Nature 2000; 408: 535-536.

4. Rauner M, Sipos W, Thiele S, Pietschmann P. Advances in osteoimmunology: pathophysiologic concepts and treatment opportunities. Int Arch Allergy Immunol 2013; 160: 114-125.

5. Blázquez-Medela AM, López-Novoa JM, Martínez-Salgado C. Osteoprotegerin and diabetes-associated pathologies. Curr Mol Med 2011; 5: 401-416.

6. Boyce BF, Xing L. Biology of RANK, RANKL, and osteoprotegerin. Arthritis Res Ther 2007; 9(Suppl 1): S1. doi:10.1186/ar2165.

7. Fata JE, Kong YY, Li J, Sasaki T, Irie-Sasaki J, Moorehead RA, et al. The osteoclast differentiation factor osteoprotegerinligand is essential for mammary gland development. Cell 2000; 103: 41-50.

8. Akiyama $\mathrm{T}$, Shimo $\mathrm{Y}$, Yanai $\mathrm{H}$, Qin J, Ohshima D, Maruyama Y, et al. The tumor necrosis factor family receptors RANK and CD40 cooperatively establish the thymic medullary microenvironment and self-tolerance. Immunity 2008; 29: 423-437.

9. Knoop KA, et al. RANKL is necessary and sufficient to initiate development of antigen-sampling $M$ cells in the intestinal epithelium. J Immunol 2009; 183: 5738-5747.

10. Shin M, Matsuo K, Tada T, Fukushima H, Furuta H, Ozeki $\mathrm{S}$, et al. The inhibition of RANKL/RANK signaling by osteoprotegerin suppresses bone invasion by oral squamous cell carcinoma cells. Carcinogenesis 2011; 32: 1634-1640.

11. Leibbrandt A, Penninger JM. RANK/RANKL: regulators of immune responses and bone physiology. Ann N Y Acad Sci
2008; 1143: 123-150.

12. Rauner M, Sipos W, Pietschmann P. Osteoimmunology. Int Arch Allergy Immunol 2007; 143: 31-48.

13. In English: Kronenberg H, Bringhurst F, Nussbaum S, Jüppner H, Abou-Samra A, Segre G, Potts J. Parathyroid hormone: biosynthesis, secretion, chemistry, and action. In: Mundy G, Martin J eds. Handbook of Experimental Pharmacology: Physiology and Pharmacology of Bone. Heidelberg: Springer; 1993. p. 185-201.

14. Coetzee M, Kruger MC. Osteoprotegerin-receptor activator of nuclear factor-kappaB ligand ratio: a new approach to osteoporosis treatment ? Southern Medical Journal 2004; 97: 506-511.

15. Weitzmann MN, Pacifici R. The role of T lymphocytes in bone metabolism. Immunol Rev 2005; 208: 154-168.

16. Weitzmann MN, Pacifici R. Role of the immune system in postmenopausal bone loss. Curr Osteoporos Rep. 2005; 3: 9297.

17. Nanes MS. Tumor necrosis factor-alpha: molecular and cellular mechanisms in skeletal pathology. Gene 2003; 321: 115.

18. Pacifici R. T cells and post menopausal osteoporosis in murine models. Arthritis Res Ther 2007; 9: 102.

19. Onal M, Xiong J, Chen X, Thostenson JD, Almeida M, Manolagas SC, O'brien CA. Receptor activator of nuclear factor kappaB ligand (RANKL) protein expression by B lymphocytes contributes to ovariectomy-induced bone loss. $J$ Biol Chem 2012; 287: 29851-29860.

20. Walsh MC, Choi Y: Biology of the RANKLRANK-OPG system in immunity, bone, and beyond. Front Immunol 2014; 5: 511 .

21. Engelmann R, Wang N, Kneitz C, Müller-Hilke B: Bone resorption correlates with the frequency of CD5 + B cells in the blood of patients with rheumatoid arthritis. Rheumatology (Oxford). 2015; 54: 545-553.

22. Breuil V, Ticchioni M, Testa J, Roux CH, Ferrari P, Breittmayer JP, et al. Immune changes in postmenopausal osteoporosis: the Immunos study. Osteoporos Int 2010; 21: 805-814.

23. Burgers TA, Williams BO. Regulation of Wnt/beta-catenin signaling within and from osteocytes. Bone 2013; 54: 244249.

24. Baron R, Kneissel M. WNT signaling in bone homeostasis and disease: From human mutations to treatments. Nat Med 2013; 19: 179-192.

25. Poole KE, Van Bezooijen RL, Loveridge N, Hamersma H, Papapoulos SE, Löwik CW, Reeve J. Sclerostin is a delayed secreted product of osteocytes that inhibits bone formation. FASEB J 2005; 19: 1842-1844.

26. Zaheer S, LeBoff M, Lewiecki EM. Denosumab for the Treatment of Osteoporosis. Expert Opin Drug Metab Toxicol 2015; 11: 461-470.

27. Maldonado-Gonzales E, Pietschmann P: An antibody against RANKL for the treatment of osteoporosis, inflammatory and malignant bone diseases. Wien Med Wochenschr 2010; 160: 458-463.

28. Cummings SR, San Martin J, McClung MR, Siris ES, Eastell R, Reid IR, et al. Freedom Trial: Denosumab for prevention of fractures in postmenopausal women with osteoporosis. N Engl J Med 2009; 361: 756-765. 
29. Padhi D, Allison M, Kivitz AJ, Gutierrez MJ, Stouch B, Wang C, Jang G. Multiple doses of sclerostin antibody romosozumab in healthy men and postmenopausal women with low bone mass: a randomized, double-blind, placebocontrolled study. J Clin Pharmacol 2014; 54: 168-178.

30. Graeff C, Campbell GM, Peña J, Borggrefe J, Padhi D, Kaufman A, et al. Administration of romosozumab improves vertebral trabecular and cortical bone as assessed with quantitative computed tomography and finite element analysis. Bone 2015; 81: 364-369.

31. McColm J, Hu L, Womack T, Tang CC, Chiang AY. Single- and multiple-dose randomized studies of blosozumab, a monoclonal antibody against sclerostin, in healthy postmenopausal women. J Bone Miner Res 2014; 29: 935-943. 32. Recknor CP, Recker RR, Benson CT, Robins DA, Chiang AY, Alam J, et al. The effect of discontinuing treatment with blosozumab: follow-up results of a phase 2 randomized clinical trial in postmenopausal women with low bone mineral density. J Bone Miner Res 2015; 30: 1717-1725.
How to cite?

Subası V. Immunology of Osteoporosis: A Short-Review.

J Immunol Clin Microbiol 2016; 1(2).

DOI: dx.doi.org/10.5455/jicm.6.20160514

Submit your next manuscript to the JICM and take full advantage of:

- Convenient online submission,

- Thorough peer review, Fast Response,

- No space constraints or color figure charges,

- Immediate publication on acceptance,

- Inclusion in Scopemed and High quality indexes,

- Research which is freely available for redistribution.

To submit your manuscript, please click on

http://www.jiacm.com

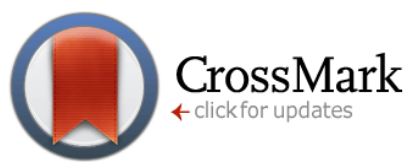

Published by The QMEL.org International Medical Education Library

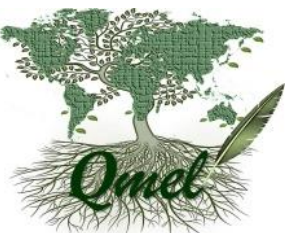

